\title{
KEDUDUKAN AHLI WARIS YANG PINDAH AGAMA MENURUT HUKUM WARIS ADAT BALI DI DESA DANGIN TUKADAYA KABUPATEN JEMBRANA
}

\author{
I Putu Endar Pranata, I Ketut Sukadana, Diah Gayatri Sudibya \\ Fakultas Ilmu Hukum Universitas Warmadewa, Denpasar - Bali, Indonesia \\ pranataendar@gmailcom, sukadanafhunwar@gmailcom, diahgayatrisudibya@gmailcom
}

\begin{abstract}
Abstrak
Persolan pindah agama pada pewarisan berdasarkan hukum adat Bali menjadi perihal yang amat pokok. Pada norma adat waris di Bali pewarisan merupakan sistem pelimpahan tanggung jawab dari satu generasi kepada keturunan berikutnya. Tanggung jawab tersebut disertai dengan pelekatan suatu hak. Tanggung jawab ini termasuk tanggung jawab di masyarakat adat. Penelitian ini dilakukan dengan tujuan mendeskripsikan bagaimana hubungan kekeluargaan anak laki-laki yang beralih agama dan bagaimana kedudukan ahli waris yang pindah agama menurut hukum waris adat Bali di Desa Dangin Tukadaya Kabupaten Jembrana. Penelitian ini menggunakan jenis penelitian hukum empiris dengan pendekatan sosiologi hukum. Hasil penelitian ini menunjukkan bahwa hubungan kekeluargaan anak laki-laki yang beralih agama masih erat dengan keluarganya. Peralihan agama tidak memutuskan hubungan kekeluargaan, tetapi hak dan kewajibannya tidak lagi beruhubungan dengan sanggah kemulan desa adat dan pura desa karena dinilai telah melakukan suatu perbuatan durhaka. Selain itu, kedudukan ahli waris yang pindah agama menurut hukum waris adat Bali di Desa Dangin Tukadaya Kabupaten Jembrana adalah tidak lagi berkedudukan sebagai ahli waris karena tidak memiliki hubungan dengan Sanggah Desa Adat dan Pura Desa dan dianggap telah menjadi orang yang durhaka.
\end{abstract}

Kata Kunci: Ahli Waris; Kedudukan; Pindah Agama

\begin{abstract}
The issue of changing religions related to inheritance based on Balinese customary law is a very important matter. In the customary norms of inheritance in Bali, inheritance is a system of transferring responsibility from one generation to the next. This responsibility goes with the attachment of a right. This responsibility includes responsibilities within the indigenous community. This research was conducted with the aim of describing how the kinship relationship of a son who converted and how the position of an heir who converted according to Balinese traditional inheritance law in Dangin Tukadaya Village, Jembrana Regency. This research employed empirical legal research with a sociology of law approach. The results of this research showed that the kinship of a son who converted is still close to their families. The conversion of religion does not break the kinship relationship, but its rights and obligations are no longer related to Sanggah Desa Adat and Pura Desa for having committed an act of disobedience. In addition, the position of a heir who changed religion according to Balinese traditional inheritance law in Dangin Tukadaya Village, Jembrana Regency is no longer an heir because he has no relationship with Sanggah Desa Adat and Pura Desa and has become a disobedient person.
\end{abstract}

Keywords: Inheritance; Position; Coversion of Religion

\section{PENDAHULUAN}

Indonesia terdiri dari ribuan pulau dan mempunyai beraneka macam suku agama bahasa dan adat istiadat yang mempunyai kontras meskipun ada pula persamaannya. Begitu juga mengenai syarat atas pewarisan terkandung beraneka variasi hukum adat yang tak dapat pisah pada aktivitas masyarakat di berbagai pelosok desa di Indonesia. Dari setiap kelompok atau individu di masing-masing pelosok daerah terpandang selalu taat atas norma adatnya yang kerap dikatakan hukum tak tertera. Hukum yang sudah menjadi kebiasaan pada batin setiap warga masyarakat bisa tampak pada kehidupan sehari-hari masyarakat tersebut (Christiani, 2016). 
Budaya yang hidup pada masyarakat memiliki norma adat yang bisa disebut berkarakter tradisional. Oleh karenanya, norma adat bisa mengiringi kemajuan dan pertumbuhan masyarakat beserta mendapat berbagai dampak dari kebudayaan (Salim, 2016).

Masyarakat Indonesia memiliki variasi dalam agama dan kebudayaan termasuk berbagai macam variasi pada tatanan hukum adat di Indonesia. Persoalan ini pula sebagai efek terjajahnya Indonesia sama Belanda sebab waktu masa kolonial, Belanda bermaksud membagi aliansi bangsa Indonesia menjadi berbagai kalangan kaum dan juga berbagai sistem hukum. Negara Republik Indonesia hingga kini menggunakan norma waris yang sifatnya beragam (Suwondo, 1981).

Beberapa penelitian sebelumnya mengungkap bahwa di Bali seseorang akan kehilangan kedudukannya sebagai ahli waris jika telah berpindah agama dari agama Hindu ke agama lain. Hal ini tentu dilatarbelakangi oleh hukum adat dan kepercayaan yang ada di Bali (Artatik, Saputra, \& Apsaridewi, 2020; Dewi, 2020; Prabowo, Windia, \& Wirawan, 2018).

Berdasarkan latar belakang di atas, penelitian ini dilakukan untuk mendeskripsikan bagaimana hubungan kekeluargaan anak laki-laki yang beralih agama dan bagaimana kedudukan ahli waris yang pindah agama menurut hukum waris adat Bali di Desa Dangin Tukadaya Kabupaten Jembrana.

\section{METODE PENELITIAN}

Penelitian ini didesain dengan menggunakan metode penelitian hukum empiris. Penelitian ini menggambarkan hukum tertulis tentang tingkah laku masyarakat dalam berinteraksi. Dengan kata lain, penelitian ini mengungkapkan hukum yang tertera dalam kalangan masyarakat dengan perilaku yang dilakukan pada masyarakat (Muhammad, 2004). Penelitian ini juga menggambarkan salah satu perilaku jelas sebagai data primer didapat dari data penelitian terjun langsung ke objeknya. Pendekatan Masalah dalam penelitian ini adalah pendekatan sosiologi hukum, yaitu melihat atau memahami hukum secara nyata dalam praktiknya di masyarakat.

Sumber data penelitian ini adalah data primer yang berupa keterangan yang dikumpulkan dengan langsung turun ke oyek yang ingin di teliti dan data sekunder yang berupa keterangan yang dapat diambil dari bahan pustaka seperti dokumen resmi buku hasil penelitian. Data sekunder ini juga menggunakan bahan hukum, yaitu Undang-Undang Dasar 1945. Data dikumpulkan dengan menggunakan metode wawancara yang merupakan aktivitas tanya jawab langsung yang dilakukan oleh dua orang maupun lebih mengenai suatu permasalahan penelitian, metode observasi yang merupakan suatu aktivitas pengambilan data dengan melakukan pemeriksaan langsung pada objek dalam suatu penelitian, dan metode pencatatan terhadap kasus yang diteliti berdasarkan buku atau dokumen resmi yang berwujud laporan.

\section{HASIL DAN PEMBAHASAN}

\section{Hubungan Kekeluargaan Anak Laki-Laki yang Beralih Agama menurut Hukum Waris Adat Bali di Desa Dangin Tukadaya Kabupaten Jembrana}

Hukum kekeluargaan merupakan aturan tentang hukum yang bersangkutan dengan kekeluargaan, sedarah, dan juga ikatan perkawinan (Koentjaraningrat, 1998). Sistem kekerabatan atau kekeluargaan merupakan hubungan keluarga melalui suatu proses perkawinan. Masyarakat hukum adat di Indonesia menganut bermacam corak sistem kekerabatan, di antaranya matrilineal, patrilineal, dan bilateral. Sistem keluarga matrilineal ini memuat turunan dari anak cewek seperti kaum Minangkabau. Demikian juga sistem kekerabatan patrilineal memuat turunan dari anak laki seperti di Bali. Sedangkan bilateral memuat turunan dari kedua anak (laki dan perempuan) seperti kaum Jawa (Uli, 1999).

Dalam hukum adat yang sebenarnya, seseorang atau anak jika beralih ke agama lain tidak mendapatkan kekayaan warisan yang telah di tinggalkan pewaris. Jika ada seseorang atau anak yang berpindah agama mendapatkan warisan dari pewaris, maka itu hanya bersifat pemberian sukarela dari pewaris dengan pertimbangan tersendiri.

Di Desa Adat Dangin Tukadaya Kabupaten Jembrana Provinsi Bali, pengaruh peralihan agama terhadap hubungan kekeluargaan menurut Bendesa Adat Dangin Tukadaya, I Gusti Komang Pujayana, adalah hubungan kekeluargaan masih erat dalam hubungan kekeluargaanya. Pengaruh peralihan agama terhadap hubungan kekeluargaan tidak terputus, tetapi hak dan kewajibannya tidak lagi berhubungan dengan sanggah kemulan desa adat dan pura desa karena dinilai telah melakukan 
suatu perbuatan durhaka (Wawancara dengan Bendesa Adat Desa Dangin Tukadaya pada tanggal 22 juli 2020).

Hukum waris adat merupakan hukum yang mencangkup garis ketentuan tentang susunan dan asas hukum. Hukum waris mengatur wasiat waris yang dialihkan kepemilikannya pada pewaris terhadap ahli waris. Hukum waris adat juga menggambarkan hukum yang mengatur pelanjutan wasiat kekayaan kepada keturunan selanjutnya (Hadikusuma, 1990).

Hukum waris adat di Indonesia hingga kini terdiri dari berbagai macam sistem menurut tata masyarakatnya. Dalam hukum adat waris juga tak terhindar dari sistem kekeluargaan yang digunakan masyarakat tersebutnya. Sistem hukum bisa berbeda dengan aturan hukumnya masing-masing.

Sistem pewarisan di Indonesia mengenal beberapa sistem pewarisan, yaitu sistem pewarisan keturunan individual, kolektif, dan mayorat. Dalam penerusan dan pengoperan harta warisan dari pewaris kepada ahli warisnya tentu tidak bisa lepas dari ideologi bangsa, yaitu pancasila.

\section{Kedudukan Ahli Waris yang Pindah Agama menurut Hukum Waris Adat Bali di Desa Dangin Tukadaya Kabupaten Jembrana}

Dalam pelaksanaan hukum Hindu di Bali ada berbagai macam hal yang menimbulkan hak waris seseorang hilang, salah satunya adalah kalau berpindah ke agama lain. Jika berpindah agama, ahli waris tidak lagi ada hubungan dengan Sanggah Desa Adat dan Pura Desa, sehingga hak waris akan gugur.

Di Desa Adat Dangin Tukadaya Kabupaten jembrana Provinsi Bali anak laki- laki yang bernama I Putu Yudhi Erawan di tinggal meninggal dunia oleh ayahnya. Anak laki ini yang ayah dan ibunya beragama Hindu, kemudian ayahnya meninggal dunia, lalu ibunya beralih agama ke agama aslinya yaitu agama Kristen. Anak yang bernama I Putu Yudhi Erawan mengikuti agama atau keyakinan ibunya yang beragama Kristen.

Jadi si anak yang bernama I Putu Yudhi Erawan sudah beralih agama dari agama Hindu ke agama Kristen. Menurut pandangan Bendesa adat Desa Dangin Tukadaya Kabupaten Jembrana Provinsi Bali tentang Kedudukan Hukum Anak Laki-Laki Yang Beralih Agama Ke Agama Lain, beliau menyatakan bahwa Anak laki-laki yang beralih agama dari agama Hindu ke agama lain dianggap durhaka baik di keluarga dan di masyarakat sebab meninggalkan agama hindu dianggap meninggalkan leluhur dan kewajiban-kewajiban dari seorang anak laki-laki yang akan memikul kewajiban dari ayahnya. Meninggalkan agama atau beralih agama dari agama Hindu ke agama lain juga menyebabkan hak mewaris dari seorang ahli waris itu akan hilang. Oleh karena itu, kedudukan sebagai ahli waris tidak lagi jatuh ke orang atau anak tersebut, dan juga seseorang atau anak yang berpindah agama tesebut akan dicoret dari perkumpulan/krame desa adat. Dia akan terlepas dari kegiatan ayahan/persembahyangan termasuk menggunakan kuburan adat di desa tersebut.

\section{SIMPULAN DAN SARAN}

\section{Simpulan}

Berdasarkan hasil dan pembahasan di atas, ada beberapa simpulan yang dapat dibuat, yaitu: pertama, hubungan kekeluargaan anak laki-laki yang beralih agama masih erat dengan keluarganya. Peralihan agama tidak memutuskan hubungan kekeluargaan, tetapi hak dan kewajibannya tidak lagi beruhubungan dengan sanggah kemulan desa adat dan pura desa karena dinilai telah melakukan suatu perbuatan durhaka. Anak laki-laki yang beralih agama tersebut tidak bisa melaksanakan tanggung jawab selaku ahli waris seperti melakukan piodalan di sanggah atau merajan. Kedua, kedudukan ahli waris yang pindah agama menurut hukum waris adat Bali di Desa Dangin Tukadaya Kabupaten Jembrana adalah tidak lagi berkedudukan sebagai ahli waris karena tidak memiliki hubungan dengan Sanggah Desa Adat dan Pura Desa dan dianggap telah menjadi orang yang durhaka. kedudukan sebagai ahli waris tidak lagi jatuh ke orang atau anak tersebut, dan juga seseorang atau anak yang berpindah agama tesebut akan dicoret dari perkumpulan/krame desa adat. Dia akan terlepas dari kegiatan ayahan/persembahyangan termasuk menggunakan kuburan adat di desa tersebut.

\section{Saran}

Selain simpulan, ada beberapa saran yang perlu disampaikan berdasarkan hasil penelitian ini, yaitu: pertama, diharapkan prajuru adat melakukan sosialisasi secara berkelanjutan dengan pembinaan dan 
pengarahan tentang Hukum Adat Waris di seluruh Provinsi Bali yang menentukan bahwa ahli waris yang beralih agama dari agama Hindu ke agama lain apakah akan kehilangan hak mewaris harta warisan yang ditinggalkan pewaris. Hal ini perlu untuk menghindari hal-hal yang tidak diinginkan yang mungkin akan terjadi dalam masyarakat. Kedua, diharapkan agar masyarakat adat mencermati awig-awig desa adat untuk menghindari terjadinya kesalahpahaman atau terjadinya perselisihanperselisihan dalam masyarakat serta antar umat beragama. Hal ini perlu dilakukan supaya ada ketentuan hukum yang pasti yang mengatur mengenai hal tersebut.

\section{DAFTAR PUSTAKA}

Artatik, I. G. A. K., Saputra, I. G. N. A., \& Apsaridewi, K. I. (2020). Implikasi Yuridis Konversi Agama terhadap Kedudukan ahli Waris. Vidya Wertta, 3(1), 45-62.

Christiani, W. (2016). Hukum sebagai Norma Sosial Memiliki Sifat Mewajibkan. ADIL: Jurnal Hukum, 4(1), 151-167.

Dewi, D. A. H. (2020). Kedudukan Ahli Waris yang Berpindah Agama dalam Harta Waris menurut Hukum Waris Adat Bali. Jurnal Preferensi Hukum, 1(2), 78-82.

Hadikusuma, H. (1990). Hukum Perkawinan Indonesia. Bandung: Mandar Maju.

Koentjaraningrat. (1998). Pengantar Antropologi. Jakarta: Rineka Cipta.

Muhammad, A. (2004). Hukum dan Penelitian Hukum. Bandung: Citra Aditya Bhakti.

Prabowo, A., Windia, I. W., \& Wirawan, I. K. (2018). Peralihan Status Kepemilikan Tanah Warisan Menjadi Tanah Pelaba Pura dalam Masyarakat Hukum Adat Bali (Studi Kasus di Desa Adat Canggu). Jurnal Ilmiah Prodi Magister Kenotariatan, 296-304.

Salim, H. M. (2016). Adat Sebagai Budaya Kearifan Lokal untuk Memperkuat Eksistensi Adat ke Depan. Al Daulah: Jurnal Hukum Pidana Dan Ketatanegaraan, 5(2), 244-255.

Suwondo, N. (1981). Kedudukan Wanita Indonesia dalam Hukum dan Masyarakat. Jakarta: Ghalia Indonesia.

Uli, K. (1999). Warisan Leluhur Sastra Lama dan Aksara Batak. Jakarta: Gramedia. 